\title{
A Study on Water Balance in Stationary Load Proton Exchange Membrane(PEM) Fuel Cell Power Generator
}

Agung Bakhtiar* Oh, Hoo-Kyu** Yoon, Jung-In** Kim, Young-Bok*** Choi, Kwang-Hwan**

*Graduate School of Refrigeration and Air Conditioning Engineering, Pukyong National University,

**Dept. of Refrigeration and Air Conditioning Engineering, Pukyong National University,

***Dept. of Mechanical System Engineering, Pukyong National University(choikh@pknu.ac.kr)

\section{고정 부하를 갖는 $\mathrm{PEM}$ 연료전지 발전기에 있어서의 수분 평형에 관한 연구}

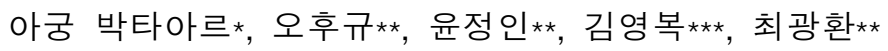

*냉동공조공학과 대학원, 부경대학교,

**냉동공조공학과, 공과대학, 부경대학교(choikh@pknu.ac.kr),

***기계시스템공학과, 공과대학, 부경대학교

\begin{abstract}
일반적으로 PEM 연료전지에서는 수분 균형이 시스템의 효율에 결정적으로 영향을 미치기 때문에, 이에 대한 균형 (balance)을 잡는 것이 매우 중요하다. 특히, 촉매 층에서 물이 넘치는 익수현상(flooding)이나 건조현상(drying)이 발 생하게 되면 연료전지의 효율이 급격하게 저하하므로, 항상 수분의 균형이 잡히도록 시스템을 제어하는 것이 일반적 이다. 이 때, 수분의 익수현상이나 건조현상은 PEM 연료전지의 용량과 주위의 환경, 즉 온도와 습도에 많은 영향을 받게 된다.

금번 논문에서는 가정용 규모인 $3 \mathrm{~kW}$ 급에서 $10 \mathrm{~kW}$ 급까지의 $\mathrm{PEM}$ 연료전지를 설치하였을 때, 주위의 환경(온도와 습도)이 수분 이동에 어떠한 영향을 미치는 지를 시간에 따라서 시뮬레이션(simulation)한 결과를 보여주고 있다. 결과 에서 유입공기의 온도가 $50^{\circ} \mathrm{C}$ 이하일 경우, 고정부하가 $5 \mathrm{~kW}$ 급 이하이면 대부분이 건조현상이 발생하였으나, 고정부하 가 $6 \mathrm{~kW}$ 급 이상이 되면 익수현상이 운전시간이 20 분 이내에서 발생하였다. 또한 고정부하를 최고 $10 \mathrm{~kW}$ 급까지 올린 경우, 유입공기의 온도가 $50^{\circ} \mathrm{C}$ 까지는 익수현상이 발생하였으나 $60^{\circ} \mathrm{C}$ 이상인 경우에는 거의 건조현상이 발생함을 알 수 있었다.
\end{abstract}

Keywords : 연료전지(Fuel cell), 모델링(Modelling), 수분평형(Water balance), 상시하중(Stationerary load), 수분포화(Water evaporation)

투고일자 : 2011년 1월 5일, 심사일자 : 2011년 1월 8일, 게재확정일자 : 2011년 8월 24일 교신저자 : 최광환(choikh@pknu.ac.kr) 


\section{Nomenclature}

$\dot{n}:$ Molar rate, $\left[\mathrm{mol} \cdot \mathrm{s}^{-1}\right]$

$n_{d} \quad$ : Electro osmotic drag coefficient

$\rho \quad:$ density, $\left[\mathrm{kg} \cdot \mathrm{cm}^{-3}\right]$

$M_{r}$ : Relative molecular mass, $\left[\mathrm{kg} \cdot \mathrm{mol}^{-1}\right]$

$\kappa \quad:$ Permeability, $\left[\mathrm{m}^{2}\right]$

$\mathrm{s} \quad$ : Liquid saturation level, [-]

$\varepsilon \quad$ : Porosity

$\mu \quad$ : Dynamic viscosity, $\left[\mathrm{m}^{2} \cdot \mathrm{s}^{-1}\right]$

$T$ : Temperature, $\left[{ }^{\circ} \mathrm{C}\right]$

$\delta$ : Thickness, [m]

$\lambda \quad:$ Latent heat, $\left[\mathrm{kJ} \cdot \mathrm{kg}^{-1}\right]$

$h$ : Heat transfer coefficient, $\left[\mathrm{W} \cdot \mathrm{m}^{-2} \cdot \mathrm{K}^{-1}\right]$

$I \quad$ : Current density, $\left[\mathrm{A} \cdot \mathrm{m}^{-2}\right]$

$A$ : Cross section area, $\left[\mathrm{m}^{2}\right]$

$F \quad$ : Faraday constant, $\left[\mathrm{C} \cdot \mathrm{mol}^{-1}\right]$

$\phi \quad:$ Humidity ratio, $\left[\mathrm{g} \cdot \mathrm{kg}^{-1}\right]$

$m$ : Mass, [kg]

$\gamma \quad:$ Specific volume, $\left[\mathrm{m}^{3} \cdot \mathrm{kg}^{-1}\right]$

$V$ : Volume, $\left[\mathrm{m}^{3}\right]$

$Q:$ Flow rate, $\left[\mathrm{m}^{3} \cdot \mathrm{s}^{-1}\right]$

$W$ : Power, [Watt]

\section{Subscript}

$\begin{array}{ll}\text { cap } & : \text { capillarity } \\ \text { evap } & : \text { evaporation } \\ \text { rct } & : \text { reaction } \\ \text { sat } & : \text { saturated } \\ \text { liq } & : \text { liquid } \\ \text { vap } & : \text { vapor }\end{array}$

\section{Introduction}

A water management in PEM fuel cell has a significant impact on the overall system performance, therefore it becomes one of the most critical issues and widely studied.
Proper water management should provide an adequate membrane hydration and avoidance of water flooding in the catalyst layer. Thus water management is a critical consideration for better design of PEM fuel cell systems. The amount of water and the disposition of water within the PEM fuel cell strongly affects efficiency and reliability [1].

The oxidation reaction that produces water in PEM fuel cell occurs actually in cathode. The flooding in cathode reduces the active reaction area and eventually decreases the performance [2]. The flooding occurs when the water production rate is higher than its removal rate. However, the flooding can also occur even at low current densities under a certain operating conditions, such as low temperatures and high humidity.

This present study proposes a water transportation model of PEM fuel cell and also gives a simulation results occurred in a stationary power generation. With this model, flooding on stationary power generation can be predicted and it will be helpful on water management system to get the water balance.

\section{Proposed model}

Based on the principles of water balance, an analytical model is developed in this section to describe PEM fuel cell. The specific assumptions for the present modelling are the followings.

1) The fuel cell is treated as a lumped system with a uniform temperature.

2) The gas mixture is an incompressible and ideal.

3) Gas diffusion layer(GDL), CCL, and membrane are isotropic and homogeneous. 
4) The voltage loss due to electronic resistances is negligible.

Water balance in cathode catalyst layer (CCL) should be based on the different amount between rate of water input and output as shown in Fig. 1.

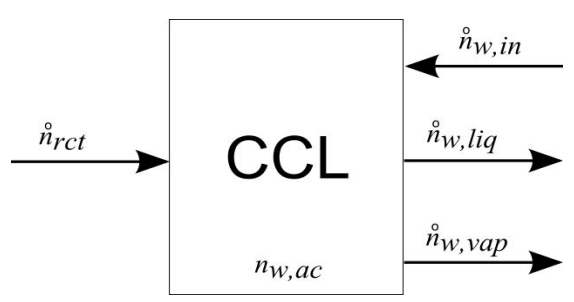

Fig. 1 Schematic of water balance in $\mathrm{CCL}$

The water generation rate in the CCL can be simplified and expressed as the amount of the water production rate from oxygen reduction reaction (ORR) and dragged from the anode side as shown in Eq. 1[2-5].

$$
\dot{n}_{r c t}=\left(n_{d}+1\right) \frac{I A}{2 F}
$$

Based on the ASHRAE standard formula to calculate the air properties[6], the input water from humid air can be then calculated by using Eq. 2 to Eq. 6 . When the water addition is less than the saturated condition, the available molar space for water addition is given by Eq. 4. The exceed water over the saturated amount turned into liquid. As long as the water input is not saturated, the water output in the vapor phase will be given by Eq. 5 and also the liquid phase given by Eq. 6 .

$$
\dot{n}_{w, i n}=\frac{\phi Q}{\gamma M_{r}}
$$

$$
\begin{aligned}
& \dot{n}_{s a t}=\frac{\phi_{s} \cdot Q}{\gamma_{s} M_{r}} \\
& \dot{n}_{\text {space }}=\dot{n}_{s a t}-\dot{n}_{w, i n} \\
& \dot{n}_{w, v a p}=\dot{n}_{w, i n}+\dot{n}_{r c t}
\end{aligned}
$$

$$
\dot{n}_{w, l i q}=\dot{n}_{w, i n}+\dot{n}_{w, r c t}-\dot{n}_{w, s a t}
$$

The liquid saturation ratio of the water in CCL is then given by Eq. 8 .

$$
\begin{aligned}
& \Delta s_{x, r c t}=\frac{\dot{n}_{w, l i q} M_{r}}{\rho \delta A \varepsilon} \\
& s_{x}=s_{0}+\Delta s_{x, r c t}
\end{aligned}
$$

Many studies are related to the steady state water transportation in GDL of PEM fuel cell [2, 5, 7, 8]. In their works, it was seen that capillarity transport is the dominant transport process to remove water from flooded GDLs. Molar flow rate of the water transported by capillarity process is given by Eq. 9. Furthermore, the liquid saturation change by capillarity process is given by Eq. 10 .

$$
\begin{gathered}
\dot{n}_{c a p}=s^{4}\left(1.417-4.240 s+3.789 s^{2}\right) \times \\
\frac{A \sigma \cos \left(\theta_{c}\right)(\varepsilon \kappa)^{0.5}}{M_{r} \mu \delta_{G D L}} \\
\Delta s_{x, c a p}=\frac{\dot{n}_{c a p} M_{r}}{\rho \delta A \varepsilon}
\end{gathered}
$$

And the liquid saturation becomes the following.

$$
s_{x}=s_{0}+\Delta s_{x, r c t}-\Delta s_{x, c a p}
$$

The continuum model of the saturation 
used in this paper can be described as cubic as shown in Fig. 2. The total volume of the cube is $\mathrm{x} 3$ with total surface area of $6 \times 2$. If a liquid phase is presented with liquid saturation level s, the surface area of liquid becomes $(4 \mathrm{~s}+2) \times 2$. Hence the water evaporation rate can be defined as a certain ratio between the heat transfer and the latent heat as given in Eq. 12 [9].

$$
\begin{aligned}
& \dot{n}_{\text {evap }}= \\
& \frac{h(4 s+2)(\varepsilon \delta A)^{2 / 3}\left|T_{l i q}-T_{a i r}\right|}{\lambda M_{r}}
\end{aligned}
$$

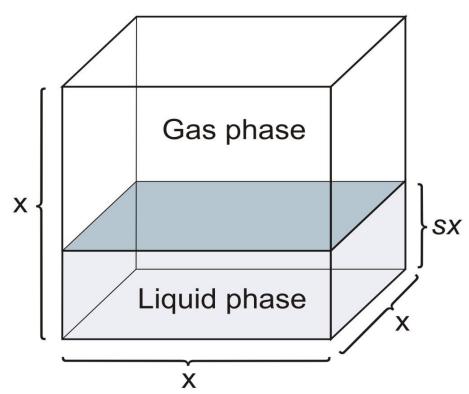

Fig. 2 Model of saturation cube

The liquid saturation change varied by evaporation process will be described as next equation.

$$
\triangle s_{x, \text { evap }}=\frac{\dot{n}_{\text {evap }} M_{r}}{\rho \delta A \varepsilon}
$$

The final liquid saturation can be also expressed as following.

$s_{x}=s_{0}+\Delta s_{x, r c t}-\triangle s_{x, c a p}-\triangle s_{x, \text { evap }}$

\section{Simulation parameters}

Table 1 shows the parameter used in this simulation with the current model. The values of these parameters is sufficient to produce the desired power demand. Among different conditions, the particular input air conditions, such as temperature, humidity, and fuel cell power load, have been changed for comparison with the amount of water transportation .

Table 1. Simulation parameters

\begin{tabular}{c|c}
\hline Parameter & Value \\
\hline $\mathrm{Q}$ & $0.08 \mathrm{~m}^{3} \mathrm{~s}^{-1}$ \\
$\mathrm{~A}$ & $0.02 \mathrm{~m}^{2}$ \\
\hline$\delta_{G D L}$ & $3.10^{-4} \mathrm{~m}$ \\
\hline $\mathrm{N}$ & 448 \\
\hline$n_{d}$ & 0.5 \\
\hline$\kappa$ & $1.810^{-18} \mathrm{~m}^{2}$ \\
\hline$\varepsilon$ & 0.6 \\
\hline$\sigma$ & $0.0625 \mathrm{~N} / \mathrm{m}$ \\
\hline$\theta_{c}$ & 120 \\
\hline$h$ & $105.28 \mathrm{~W} / \mathrm{m}^{2} \mathrm{~K}$ \\
\hline$\lambda$ & $2417.44 \mathrm{~kJ} / \mathrm{kg}$ \\
\hline
\end{tabular}

\section{Result and discussion}

The power demand of the fuel cell effects to its current density. When the power demand was high, the current density became high, therefore the water generated by fuel cell reaction was also high. The simulation in this study was conducted by using different variations of stationary power demand and the liquid saturation levels are compared as its results. Firstly, we have simulated the modeling using low temperature air. At this time the air properties of $40^{\circ} \mathrm{C}$ and $38 \%$ R.H.(relative humidity) was recognized as the representative. The results were shown in Fig. 3 and the flooding occurred on high power demand condition. 


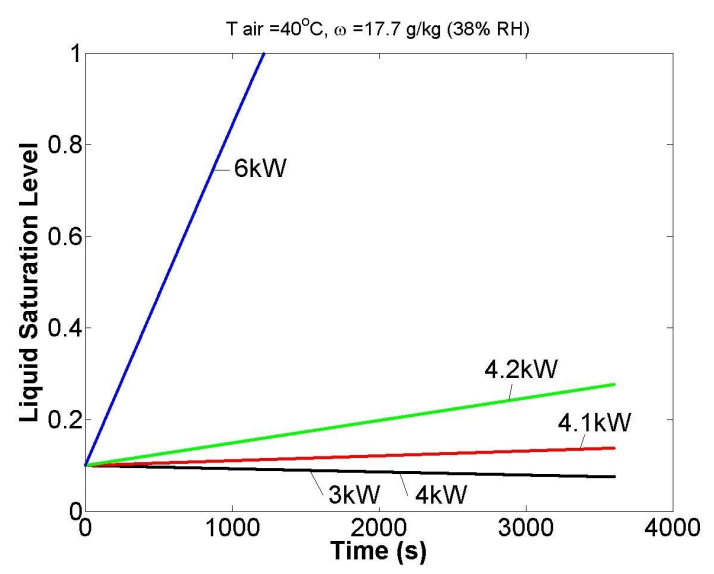

Fig. 3 Simulation results at low temperature and low humidity

The earliest flooding among the simulated has aroused at the power demand of $6 \mathrm{~kW}$. In case of $6 \mathrm{~kW}$, it began to flood sharply with starting and then flooded almost with 1,100 seconds. The reason for the flooding is because the current density was the most high and so the amount of water generated by fuel cell reaction given in Eq. 1 was high. To avoid the flooding, the input air temperature should be increased. Increasing the temperature without adding any water will increase the evaporation of the accumulated water inside the gas diffusion layer.

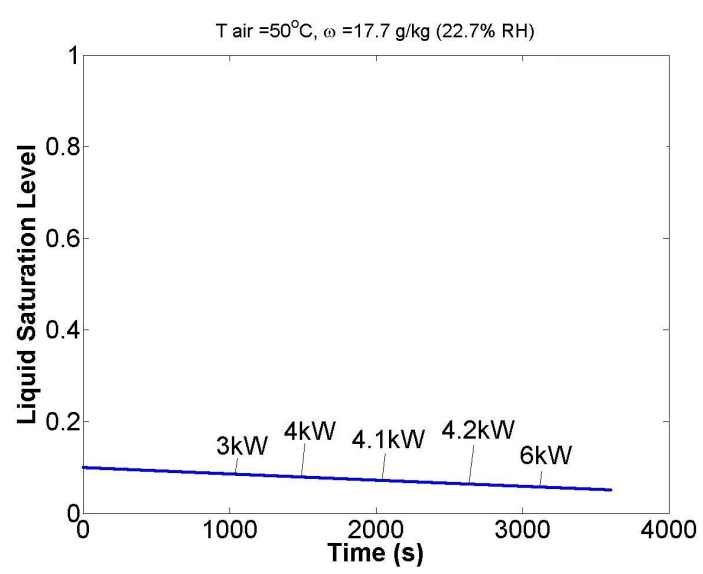

Fig. 4 Simulation results at high temperature and low humidity
Therefore, the second simulation was focused on the influence on increasing the input air temperature from $40^{\circ} \mathrm{C}$ to $50^{\circ} \mathrm{C}$ without any humidifying process. Through the simulation, it was clear that the liquid saturation level decreased the flooding, but this also caused the drying in all conditions as shown in Fig. 4.

The reason this drying happened is because the water generation and the water removal failed to strike the balance. The water removal caused by evaporation as given in Eq. 12 became higher than the water generation produced by fuel cell reaction. Therefore, in this case the total amount of water addition should be increased to avoid the drying. The increment of the water addition is usually done by adding the water into the input air. Another simulation was performed to investigate effects on increasing the humidity of the input air.

Fig. 5 has shown the simulated results after increasing only the air humidity from $22.7 \%$ (R.H.) to $50 \%$ (R.H.) at air temperature of $50^{\circ} \mathrm{C}$. Under this condition the drying and the flooding appeared at the same time. The power demand of $6 \mathrm{~kW}$ has the flooding, but below of $6 \mathrm{~kW}$ has resulted in all drying.

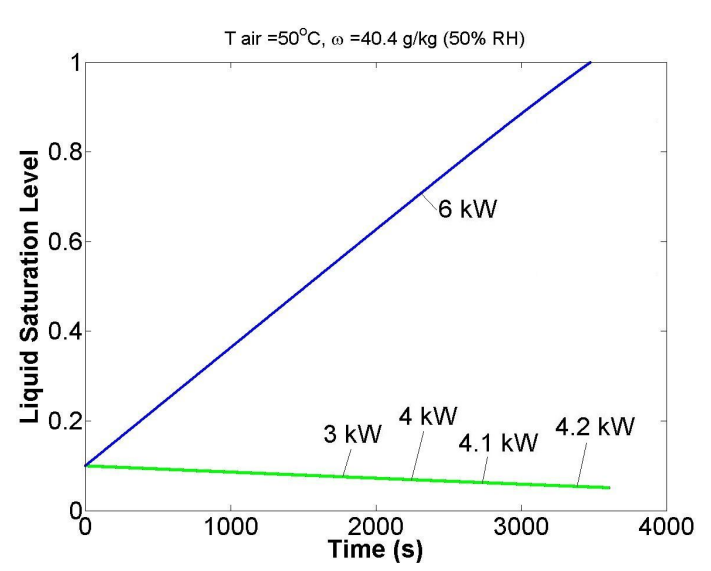

Fig. 5 Simulation results at high temperature and high humidity 
From these results, it was known that the water balance will be existed in the range of the power demand between $4.2 \mathrm{~kW}$ and $6 \mathrm{~kW}$. However, there was little changes near the power demand of $3 \mathrm{~kW}$ to $4.2 \mathrm{~kW}$. On the other hand, the $6 \mathrm{~kW}$ has shown a steady change up to the drying. So it was worth investigating the affects to close to the range of $6 \mathrm{~kW}$ and more simulations were executed by focusing on the range $5 \mathrm{~kW}$ to $6 \mathrm{~kW}$. Fig. 6 shows the results of this simulation and it bore clearly the different flooding slopes.

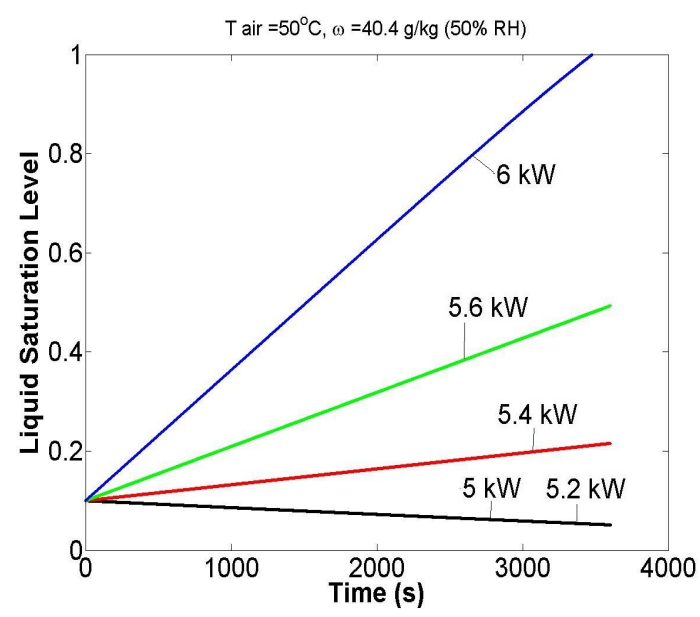

Fig. 6 Simulation results at power demand of $5 \mathrm{~kW}$ to $6 \mathrm{~kW}$

On assuming that the water balance is obtained from around the power demand of $5.6 \mathrm{~kW}$, we also performed the simulation by applying the higher power demand than its balanced point. In this simulation, the focus was on the variations with the temperature changes, $40^{\circ} \mathrm{C}$ to $60^{\circ} \mathrm{C}$, as the power demand and the humidity ratio are fixed. The simulation results were shown in Fig. 7.

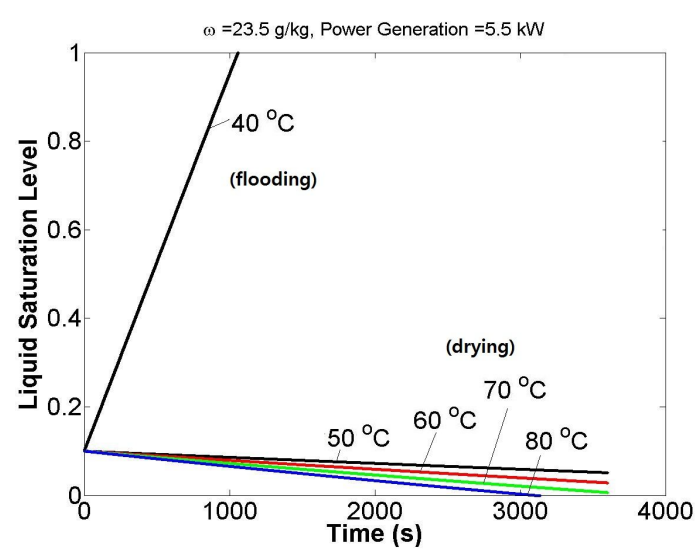

Fig. 7 Simulation results at 5kW with temperature variation

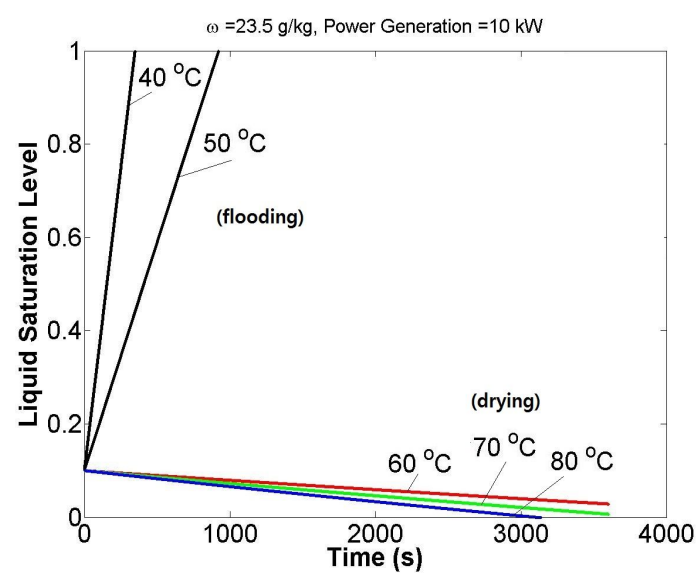

Fig. 8 Simulation results at $10 \mathrm{~kW}$ with temperature variation

These results, however, have shown that the flooding still arose from the low inlet air temperature, even the inlet air is humid. The higher air temperature is, the steeper the drying slope is. So we needed to analyze the influence specifically between $40^{\circ} \mathrm{C}$ and $50^{\circ} \mathrm{C}$ by raising the power demand up to $10 \mathrm{~kW}$ after fixing the inlet air properties same as the case of $5.5 \mathrm{~kW}$. The simulation results for this were shown in Fig. 8 and it revealed thate the flooding has even occurred not only at the $50^{\circ} \mathrm{C}$, but $40^{\circ} \mathrm{C}$. It was also clear that the difference of the power demand 
can change the sensitivity of the temperature to the liquid saturation level in Fig. 7 and Fig. 8. This means the slopes of the liquid saturation level with different inlet air properties have not linear relationship with different stationary power demand.

On the other hand, we also had to look into the tendency of liquid saturation to prove this conclusive result before reaching flooding in Fig. 8. Thus, Fig. 9 shows the liquid saturation caused by the different inlet air temperature.

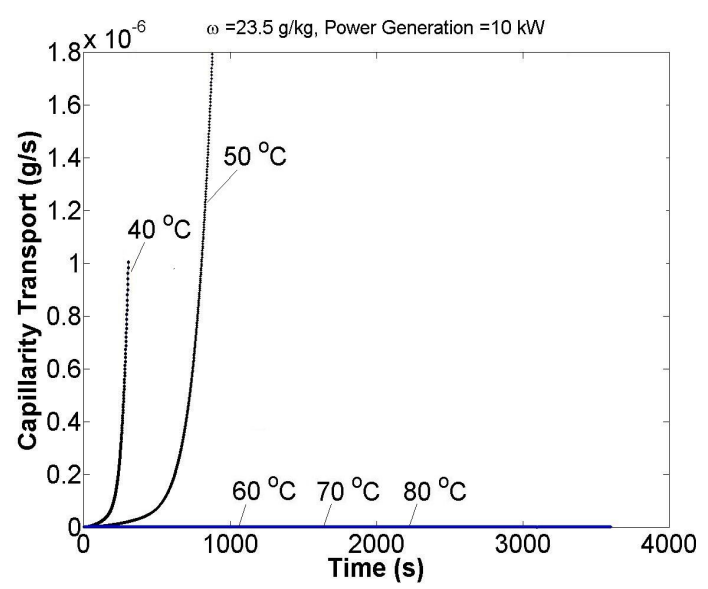

Fig. 9 Simulation results with capillarity transport in flooding

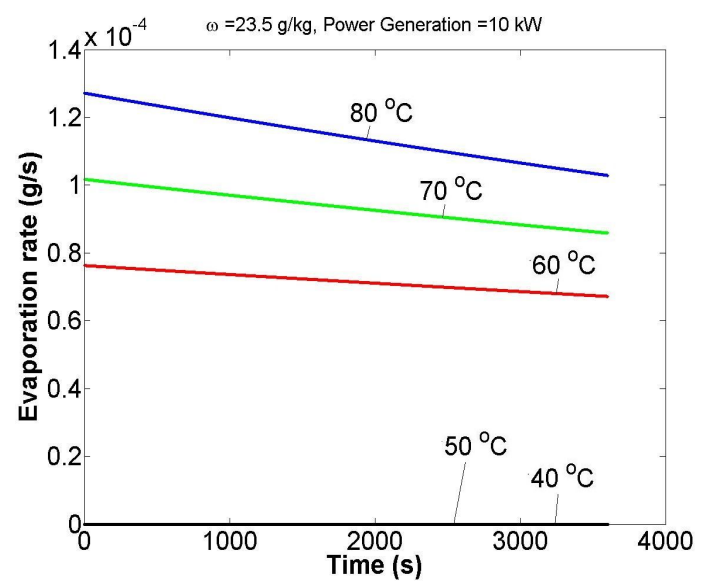

Fig. 10 Simulation results of evaporation rate
The evaporation rate in the low inlet air temperature is very small compared with the high inlet air temperature, therefore the liquid water production increases rapidly. The larger evaporation rate was acquired from higher inlet air temperature and this phenomena was described in Fig. 10.

In addition, the evaporation rates in case of $40^{\circ} \mathrm{C}$ and $50^{\circ} \mathrm{C}$ are very smaller. This is caused not only by the low temperature, but also the high humidity of the inlet air.

\section{Conclusion}

The liquid water in CCL is produced when the water vapor is condensed after saturation. If the liquid water removal is lower than liquid water adding, and then liquid water will be accumulated into the pore of CCL and also in cathode GDL. Thus, the liquid water accumulation is a vector that has a plus value when the adding rate of liquid water is greater than the removal rate of liquid water. Hence, if the accumulated water rate has a plus value and remains for long period, this will produce a flooding.

The conclusions of the simulation results are described as the following:

1. The flooding still can be happened in case of the low temperature of inlet air, even the inlet air is humidified.

2. The slopes of the liquid saturation level with different inlet air properties have not linear relationship with different stationary power demand.

3. The low evaporation rate is caused not only by the low temperature only, but 
also the high humidity of the inlet air.

\section{Reference}

1. M. G. Izenson, R. W. Hill, Proceedings of the IMECE2002, ASME International Mechanical Engineering Congress \& Exposition, pp. 147, 2002

2. Ugur Pasaogullari, C. Y. Wang, 'Liquid Water Transport in Gas Diffusion Layer of Polymer Electrolyte Fuel Cells', J. Electrochem. Soc. 154, pp. A399 - A406, 2004

3. G. Hoogers, Fuel Cell Technology Handbook. CRC Press, 2003

4. N. Sammes, Fuel Cell Technology Reaching Towards Commercialization, Springer, 2006

5. Leng Mao, Chao-Yang Wang, "Analysis of Cold Start in Polymer Electrolyte Fuel Cells," J. Electrochem. Soc. 154, pp. B139 - B146, 2007

6. ASHRAE, 2001 ASHRAE Fundamentals Handbook, New York, 2001

7. H. Ju, 'Analyzing the effects of immobile liquid saturation and spatial wettability variation on liquid water transport in diffusion media of polymer electrolyte fuel cells (PEFCs)', Journal of Power Sources, vol. 185, pp. 55-62, 2008

8. E. C. Kumbur, K. V. Sharp, and M. M. Mench, "On the effectiveness of Leverett approach for describing," Journal of Power Sources, vol. 168, pp. 356 - 368, 2007

9. Y. A. Cengel, Heat and Mass Transfer, 'A Practical Approach', 3rd edition, McGraw-Hill, 2006 